\title{
Diversification of Ramphastinae (Aves, Ramphastidae) prior to the Cretaceous/Tertiary boundary as shown by molecular clock of mtDNA sequences
}

\author{
Laila Alves Nahum ${ }^{1,2}$, Sérgio Luiz Pereira ${ }^{1,3}$, Flora Maria de Campos Fernandes ${ }^{1,4}$, Sergio Russo Matioli ${ }^{1}$ \\ and Anita Wajntal ${ }^{1}$ \\ ${ }^{1}$ Departamento de Biologia, Instituto de Biociências, Universidade de São Paulo. São Paulo, SP, Brazil. \\ ${ }^{2}$ Alellyx Applied Genomics, Campinas, SP, Brazil. \\ ${ }^{3}$ Centre for Biodiversity and Conservation Biology, Royal Ontario Museum, Toronto, Canada. \\ ${ }^{4}$ Laboratório de Biologia Molecular, Museu de Zoologia, Universidade de São Paulo, São Paulo, Brazil.
}

\begin{abstract}
Partial cytochrome $b$ and 12S rDNA mitochondrial DNA sequences of eight representatives of the Ramphastidae family were analyzed. We applied the linearized tree method to identify sequences evolving at similar rates and estimated the divergence times among some of the taxa analyzed. After excluding Ramphastos tucanus and Capito dayi from our data set, the remaining taxa presented a constant rate of DNA substitution, and branch lengths could be re-estimated with a clock constraint using the maximum likelihood method. Branch lengths were calibrated assuming that Galliformes and Piciformes split around 100 million years ago (mya). Our results indicate that Ramphastinae, and probably Capitoninae, diverged from other Piciformes in the Late Cretaceous ( 82 mya), suggesting that Piciformes is another avian order that survived the mass extinction event occurred 65 mya at the Cretaceous/Tertiary $(\mathrm{K} / \mathrm{T})$ boundary. The divergence times estimated within the Ramphastinae genera cover the period from the Middle Eocene (around 47 mya) through the Late Miocene (9.5 mya). Our estimate of divergence time is coincidental with the split of the African and the South American continents and other intense geologic activities and modifications of the areas which correspond to the current Neotropics. These events might have influenced the diversification of Ramphastinae in South America.
\end{abstract}

Key words: divergence times, K/T, mass extinction, cytochrome $b, 12 \mathrm{~S}$ rDNA, paleogeography, phylogeny.

Received: September 10, 2002; Accepted: August 4, 2003.

\section{Introduction}

The biodiversity of Neotropical regions ranks amongst the highest in the world. To better understand the mechanisms that generated such high levels of biodiversity, we should be able to identify when, where and how the separation between taxa occurred.

Whenever a representative fossil record from various strata of different ages is available, it makes it possible to trace back the origin of modern taxa and obtain reliable estimates of splitting events. However, fossil records are rather poor in the Neotropics as compared to those of other regions of the world. Although reliable dating of diversification events between taxa is available for plants through valuable information on pollen records and petrified wood,

Send correspondence to Anita Wajntal. Universidade de São Paulo, Instituto de Biociências, Departamento de Biologia, Rua do Matão 277, sala 215, 05508-900 São Paulo, SP, Brazil. E-mail: aniwa@usp.br. and even for some marine and aquatic fauna (e.g. Petri and Fulfaro, 1988), such information is very scarce for mammals and, except for some records on ancient birds, practically nonexistent for modern genera of birds. However, a few extinct species of Neotropical birds belonging to modern genera have been described for the Pleistocene (Alvarenga, 1993).

In the absence of fossil records, DNA sequencing and analysis is one of the available tools to estimate divergence times. This approach allows formulating hypotheses about the events related to taxa differentiation by comparing the estimated time elapsed since splitting of taxa with well-documented paleogeological and paleoclimatic events. For example, estimates for intergeneric diversification in the Neotropical avifauna are available for Psittacidae (Miyaki et al., 1998) and Cracidae (Pereira et al., 2002) and might provide valuable clues regarding the origin of taxa diversification in the Neotropics. 
The family Ramphastidae occurs from Mexico through Argentina and comprises 55 species of Neotropical birds belonging to two subfamilies: Ramphastinae (toucans and aracaris, six genera) and Capitoninae (New World barbets, three genera) (Sibley, 1996). The interest in this group has been increasing exponentially, and several recent papers have reported on comparative studies on morphology, isozymes, hybridization and molecular sequences (e.g. Höfling, 1998; Castro et al., 2002; Barker and Lanyon, 2000). Barker and Lanyon (2000) analyzed 888 cytochrome $b$ base-pairs from at least two species of each genus through a plethora of weighting schemes for maximum parsimony (MP) and proposed a phylogenetic hypothesis involving all Ramphastidae genera. Their results indicated Capitoninae (New and Old World barbets) as well as New World barbets to be paraphyletic, as suggested before (Prum, 1988; Sibley and Ahlquist, 1990), besides a very robust topology among the toucans and aracaris (Ramphastinae). Among these, the clade leading to Ramphastos was the first to split off, followed by Aulacorhynchus as a sister to ((Andigena, Selenidera), (Baillonius, Pteroglossus)). Maximum likelihood (ML) tests showed similar results, and most topological differences observed among ML and some of the MP weighting schemes might be related to stochastic errors due to small sequence sampling. The authors observed evolutionary rate variation among taxa, but they made no attempt to estimate the divergence time for any of the studied taxa.

Therefore, in the present study, we applied the linearized tree method (Takezaki et al., 1995) to a data set of partial mitochondrial cytochrome $b$ (cyt $b$ ) and the small ribosomal subunit $12 \mathrm{~S}$ rDNA sequences of all six valid
Ramphastinae genera and one Capitoninae genus. We identified the taxa, which evolved at a rate that was significantly different from the others, and estimated the divergence times among those taxa, which evolved within the average rate. We also discuss a possible evolutionary scenario for their diversification, based on events of the history of Earth.

\section{Material and Methods}

\section{DNA sequencing}

Total DNA was extracted from blood samples from seven Ramphastinae and one Capitoninae representatives (Table 1) as described elsewhere (Bruford et al., 1992). The DNA samples were used in PCR amplifications done in a final volume of $10.0 \mu \mathrm{L}$ containing $20 \mathrm{ng}$ of total DNA, polymerase buffer (Jeffreys et al., 1988), $1.0 \mu \mathrm{M}$ of each primer, and 2.5 units of Taq DNA polymerase (Perkin Elmer). The primers employed to amplify and sequence a portion of the cyt $b$ gene were L14841 and H15149 (Kocher et al., 1989), H16065 (Kornegay et al., 1993), reverse L (Cheng et al., 1994), L-internal, H-internal 2 and H-internal 3 (Miyaki et al., 1998). The $12 \mathrm{~S}$ rDNA L and 12S rDNA H primers (Miyaki et al., 1998) were used to amplify a portion of the 12S rDNA gene. Thirty DNA amplification cycles were carried out, consisting of denaturation for $1 \mathrm{~min}$ at $95^{\circ} \mathrm{C}$, annealing for $30 \mathrm{~s}$ at $50{ }^{\circ} \mathrm{C}$, and extension for $40 \mathrm{~s}$ at $72{ }^{\circ} \mathrm{C}$ each, using a TC2400 thermocycler (PE Applied Biosystems). An initial denaturation step of $5 \mathrm{~min}$ at $95^{\circ} \mathrm{C}$ preceded the amplifications. A final extension step of $5 \mathrm{~min}$ at $72{ }^{\circ} \mathrm{C}$ was utilized. PCR products were separated on a $1 \%$ agarose gel and recovered in a 15\% PEG8000 solution prepared with TBE buffer (Zhen and Swank, 1993). These

Table 1 - Cyt $b$ and 12S rDNA sequences of taxa analyzed in the present study.

\begin{tabular}{|c|c|c|c|}
\hline \multirow[t]{2}{*}{ Species } & \multirow[t]{2}{*}{ Taxonomic unit } & \multicolumn{2}{|c|}{ GenBank accession number } \\
\hline & & Cyt $b$ gene & $12 \mathrm{~S}$ rDNA gene \\
\hline Andigena laminirostris & Ramphastinae & AF100555 & AF255797 \\
\hline Aulacorhynchus prasinus & Ramphastinae & AF 100550 & AF255798 \\
\hline Baillonius bailloni & Ramphastinae & AF100553 & AF255799 \\
\hline Pteroglossus beauharnaesii & Ramphastinae & AF100551 & AF255800 \\
\hline Selenidera maculirostris & Ramphastinae & AF100552 & AF255801 \\
\hline Ramphastos toco & Ramphastinae & AF100554 & AF255802 \\
\hline Ramphastos tucanus $^{1}$ & Ramphastinae & AF123522 & AF255803 \\
\hline Capito dayi $i^{2}$ & Capitoninae & AF 123525 & AF255804 \\
\hline Melanerpes carolinus & Picidae & U89192 & U89209 \\
\hline Sphyrapicus varius & Picidae & U89193 & U89208 \\
\hline Crax blumenbachii ${ }^{3}$ & Cracidae & AF165468 & AF165444 \\
\hline Gallus gallus $^{4}$ & Phasianidae & X52392 & X52392 \\
\hline
\end{tabular}

1: cyt $b$ (Lanyon \& Hall, 1994) and 12S rDNA (present work).

2: cyt $b$ (Barker \& Lanyon, 2000) and 12S rDNA (present work).

3 : both cyt $b$ and $12 \mathrm{~S}$ rDNA (Pereira et al., 2002).

4: complete genome (Desjardins and Morais, 1990). 
samples were then used in DNA sequencing reactions. A single PCR product of the expected size for cyt $b$ and $12 \mathrm{~S}$ rDNA genes was visualized on the agarose gel.

Sequencing reactions were prepared using either the Dye Terminator Cycle Sequencing kit (PE Applied Biosystems) or the Thermo Sequenase Dye Terminator Cycle Sequencing kit (Amersham Life Science), according to the manufacturer's instructions. The samples were submitted to electrophoresis on an ABI PRISM 310 Genetic Analyzer (PE Applied Biosystems). Chromatograms of both strands of each gene were compared and the ambiguities were visually corrected using the Sequence Navigator software (version 1.0.1, PE Applied Biosystems; Parker, 1997). The GenBank accession numbers of all sequences obtained are listed in Table 1. This table also shows the accession numbers of Lanyon and Hall's (1994) Ramphastos tucanus sequence and Barker and Lanyon's (2000) Capito dayi sequence, which were included in our analyses.

The corresponding sequences from two other Piciformes (Melanerpes carolinus and Sphyrapicus varius) (Espinosa de los Monteros, 2000) and two Galliformes representatives (Crax blumenbachii and Gallus gallus) (Pereira et al., 2002; Desjardins and Morais, 1990) were included in the phylogenetic analysis, and their accession numbers are also shown in Table 1. The sequences were aligned in Clustal W (Thompson et al., 1994) and visually checked for misaligned positions in MacClade (version 3.08, Maddison and Maddison, 1992).

\section{Phylogenetic analysis}

Cyt $b$ and 12S rDNA sequences were tested for multiple hits by plotting uncorrected distances against the number of transition and transversion for all pairwise comparisons. These analyses were carried out using MEGA (version 2.1, Kumar et al., 2001). All three codon positions of the cyt $b$ sequences were included in the data set for the tree reconstruction. Sites containing missing information in both sequence sets and the gaps found in $12 \mathrm{~S}$ rDNA sequences were excluded. Both cyt $b$ and $12 \mathrm{~S}$ rDNA sequences were concatenated in one final data set.

Tree reconstruction was performed by means of the branch and bound algorithm under maximum parsimony (MP) and maximum likelihood (ML) criteria, using PAUP* (version 4.0b8, Swofford, 2002) and selecting Crax blumenbachii and Gallus gallus as outgroups. To identify the best model of evolutionary changes for the ML analysis, the data set was subjected to the hierarchical likelihood ratio test (LRT, Huelsenbeck and Rannala, 1997), carried out using Modeltest (version 3.0, Posada and Crandall, 1998). In this case, it tested whether the addition of parameters (such as unequal base frequency, rates of transition between purines and between pyrimidines, rates of transversions, proportion of invariable sites, and rate variation among sites) significantly improved the likelihood of the ML tree. Rate variation among sites was accounted for by three different assumptions. First, it was assumed that a proportion of sites is invariable (I) and that the variable sites evolve at the same rate; second, that all sites evolve according to a discrete gamma distribution $(\mathrm{G})$; and finally that, differently from the first assumption, the variable sites are allowed to evolve according to G. The parameters obtained by Modeltest were used as user-defined parameters in PAUP, to speed up likelihood computation.

Support for nodes in our reconstructions was obtained by jackknifing our data set in PAUP. Two sets of analysis were performed in this case, one assuming $30 \%$ and the other $50 \%$ deletion in each replicate, for 100 replicates. The purpose of the jackknife analysis was to measure the robustness of the Ramphastid phylogeny with a more reduced data set.

To determine whether the taxa included in our analysis evolved at the same rate, we performed a LRT. In this case, we tested whether likelihood values for trees with and without the assumption of a clock-like mode of evolution (Felsenstein, 1981) are significantly different. Unfortunately, the LRT was significant, suggesting that at least one sequence had an evolutionary rate that was significantly different from the others.

There are options available to determine divergence time in the absence of a general molecular clock. Some methods allow rates to differ among lineages (Sanderson, 1997; Thorne et al., 1998) and others accept rate variation at any point of the tree (Huelsenbeck et al., 2000). However, these studies present limitations and should be further investigated (Yoder and Yang, 2000). Alternatively, finding out which taxa evolve at a lower or higher rate than the average would help selecting and excluding the atypically evolving taxa. The analysis could then be performed with only those taxa, which evolve at similar rates (Takezaki et al., 1995; Rambaut and Bromham, 1998). The linearized tree method (Takezaki et al., 1995) consists of two different tests (two-cluster and branch-length), which seem to yield similar results and have been widely applied, for instance, in estimates of divergence time for the origin of orders of birds and mammals (Hedges et al., 1996), drosophilid species (Russo et al., 1995; Takezaki et al., 1995) and hominoids (Takezaki et al., 1995). Both tests require an outgroup in order to root the tree. The two-cluster test identifies statistical differences between the average substitution rates of two clusters joined by an interior node. This information allows eliminating those clusters that differ from the average root-to-tip distance. On the other hand, the branch-length test allows the identification of taxa evolving significantly faster or slower than the average. We decided to test for clock-like behavior through the branch-length tests implemented in the LinTree software (Takezaki et al., 1995). Here, we eliminated taxa evolving at significantly different rates and performed another round of the test, until no significantly different evolution rates 
were found among sequences (Takezaki et al., 1995), and molecular clock assumption was possible.

After excluding taxa with significantly different rates, we re-estimated branch lengths through maximum likelihood, assuming rate constancy among taxa and using the evolutionary model that best fit the data. We assumed that Galliformes diverged from other neognaths in the Cretaceous around 100 mya, as proposed by Paton et al. (2002). Standard errors for time estimates were obtained by non-parametric bootstrapping of our original data set.

\section{Results}

Our final alignment comprised 1160 sites (846 sites for cyt $b$, and 314 sites for $12 \mathrm{~S}$ rDNA sequences). After the exclusion of the sites containing missing information and gaps, a total of 1128 sites were used for the phylogenetic reconstruction. No indels were present in the aligned cyt $b$ sequences, and the translated amino acid sequences were highly similar to other vertebrate cyt $b$ sequences available in the GenBank. The $12 \mathrm{~S}$ rDNA sequences were also very similar to those described for other Piciformes and other birds deposited in the GenBank. Third codon positions of the cyt $b$ sequences were saturated by multiple hits, as shown by comparisons between families, but not within families (data not shown). It has been shown that third codon positions can negatively affect parsimony analyses if saturated (Barker and Lanyon, 2000). However, these positions do contain phylogenetic information (Björklund, 1999; Edwards et al., 1991; Hastad and Björklund, 1998; Källersjö et al., 1999; Yoder and Yang, 2000) and were therefore maintained in our analyses.

Base composition among variable sites of the combined cyt $b$ and 12S rDNA sequences was homogeneous among the taxa analyzed, except for Capito dayi $(p=0.001)$. The transition/transversion ratio estimated from the data set was equal to 2.21. Among the sites analyzed, 658 were invariable and 107 were parsimony informative. Mean uncorrected distances were $0.128 \pm 0.031$ substitutions per site among the Ramphastidae, $0.175 \pm$ 0.016 substitutions per site among the Piciformes, and $0.186 \pm 0.014$ substitutions per site between Piciformes and Galliformes.

Tree topologies revealed by MP and ML analysis in the present work are presented in Figure 1 and are mostly congruent with those published by Barker and Lanyon (2000). The same tree topology was obtained when these genes were analyzed separately by either MP or ML.

LRTs revealed that the model which best fit the pattern of nucleotide substitutions found for these sequences was the transversional model (TVM, assuming unequal base frequency, different transition and transversion rates; Posada and Crandall, 1998), accounting for rate heterogeneity of substitutions among sites. Results are shown in Table 2 .

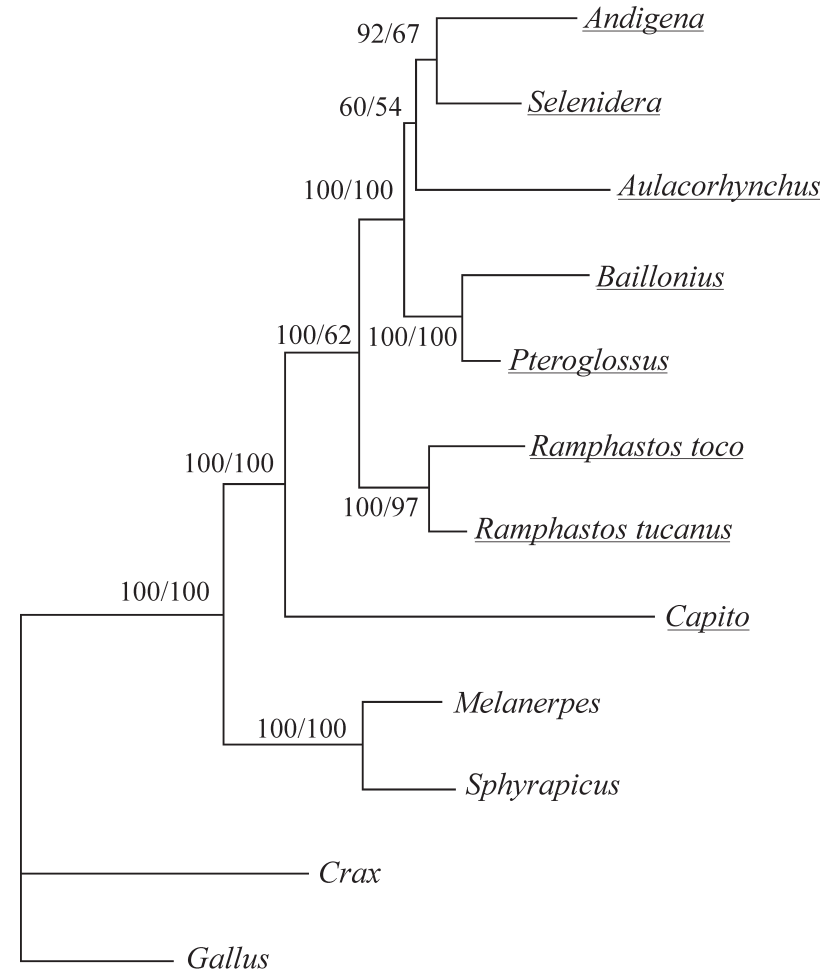

0.1

Figure 1 - Ramphastinae phylogeny estimated by cyt $b$ and $12 \mathrm{~S}$ rDNA sequences under the maximum likelihood criterion using the treebisection-reconnection algorithm on PAUP* 4.0b8. Numbers correspond to $30 \%$-deletion $/ 50 \%$-deletion jackknife proportions. Ramphastidae members are underlined. The remaining taxa are Piciformes, except for Galliformes, Crax and Gallus, used as outgroup. Note the short and long branch lengths for $R$. tucanus and $C$. dayi, respectively. The scale bar corresponds to the expected proportion of nucleotide substitution per site. See results for likelihood value and parameters for this tree.

We applied the LRT to test the molecular clock hypothesis and found that it did not support a clock-like behavior of nucleotide substitutions of the analyzed sequences. This result prevented the estimation of the divergence times among the Ramphastidae (log-likelihood without clock $=-2966.38, \log$-likelihood with clock $=$ $-2979.43 ; \chi^{2}=26.10$, d. f. $=10, p=0.0036$ ). Thus, to select only the constantly evolving sequences, so that the molecular clock could be assumed, we performed the branch-length test. The results (Table 3) showed that $R$. tucanus and $C$. dayi have nucleotide substitution rates, which are lower and higher, respectively, than those of the remaining taxa (at $\alpha=0.05$, Figure 1 ).

Finally, after excluding $R$. tucanus and $C$. dayi from our data set, the remaining taxa presented similar rates of nucleotide substitutions, and thus branch lengths could be re-estimated with the clock constraint (Figure 2). Assuming that the Galliformes-Piciformes split occurred around 100 million years ago (mya, Paton et al., 2002), our estimates indicate that toucans and aracaris have diverged from other Piciformes around 82 mya (Table 4). Also, it is possible to 
Table 2 - Hierarchical Likelihood Ratio Tests (HLRTs) performed for seven hypotheses of DNA substitution for our combined cyt $b$ and $12 \mathrm{~S}$ rDNA sequences.

\begin{tabular}{llcccc}
\hline Hypothesis & $\mathrm{H}_{0} \times \mathrm{H}_{1}$ & $-\ln \mathrm{H}_{0}$ & $-\operatorname{lnH}_{1}$ & $\mathrm{p}$ & $\mathrm{d} . \mathrm{f}$. \\
\hline Equal base frequencies & $\mathrm{JC69} \times \mathrm{F} 81$ & 3228.3459 & 3207.5066 & $<0.000001^{*}$ & 3 \\
Equal rates of transition and transversion & $\mathrm{F} 81 \times \mathrm{HKY} 85$ & 3207.5066 & 3129.1554 & $<0.000001^{*}$ & 1 \\
Equal Transition rates & HKY85 x TN93 & 3129.1554 & 3128.0161 & 0.131857 & 1 \\
Equal transversion rates & HKY85 x K81+uf & 3129.1554 & 3125.2180 & 0.005035 & 1 \\
Only two transversion rates & K81uf x TVM & 3125.2180 & 3104.2114 & $<0.000001^{*}$ & 2 \\
Equal rates among sites & TVM x TVMG & 3104.2114 & 2951.8689 & $<0.000001^{*}$ & 1 \\
No Invariable sites & TVMG x TVMIG & 2951.8689 & 2950.9290 & 0.170347 & 1 \\
\hline
\end{tabular}

Rate matrix: $[\mathrm{A}-\mathrm{C}]=4.52 ;[\mathrm{A}-\mathrm{G}]=9.83 ;[\mathrm{A}-\mathrm{T}]=2.96 ;[\mathrm{C}-\mathrm{G}]=0.87 ;[\mathrm{C}-\mathrm{T}]=13.96 ;[\mathrm{G}-\mathrm{T}]=1.0$. Base frequencies for $\mathrm{A}, \mathrm{C}, \mathrm{G}$ and $\mathrm{T}$, respectively, $0.2487,0.2889,0.1694,0.2659$. Gamma distribution shape parameter $=0.187 . \mathrm{H}_{0}$ : null hypothesis; $\mathrm{H}_{1}$ : alternative hypothesis; $\mathrm{L}_{0}$ : likelihood under $\mathrm{H}_{0}$; $\mathrm{L}_{1}$ : likelihood under $\mathrm{H}_{1}$; d.f.: degrees of freedom; $\Gamma$ : gamma distribution. * - significant at 0.005 .

estimate the generic diversification within the subfamily Ramphastinae occurred from the Middle Eocene (around 47 mya) to the Late Miocene (9.5 mya). The divergence time between Ramphastinae and Capitoninae (represented in this study by $C$. dayi) could not be estimated because the sequences of $C$. dayi did not evolve at the same rate as other Ramphastids. It should, however, be prior to the separation between toucans and aracaris, as Capitoninae is a sister group to Ramphastinae (Figure 1).

\section{Discussion}

In our study, partial cyt $b$ and $12 \mathrm{~S}$ rDNA sequences of eight Rhamphastidae representatives were aligned to correspondening sequences of two other Piciformes and two Galliformes. The evolutionary hypothesis provided in our study and that of Barker and Lanyon (2000) are very congruent showing the robustness of the classification at the generic level and therefore no further comments on the tree topologies will be made. However, we will focus on estimates of divergence times for the genera within the subfamily Rhamphastinae.

Estimation of divergence times based on molecular data is a common practice in phylogenetic studies (e.g. Arnaiz-Villena et al., 1999; García-Moreno and Silva, 1997; van Tuinen et al., 1998) and could offer insight into temporal mode (e.g. rates of diversification) or historical determinants of diversification, as geologically induced vicariance. Fossil data (e.g., Fleischer et al., 1998) and biogeographic events (e.g., García-Moreno and Mindell, 2000) can be used as calibration points for estimating molecular divergence times (Smith, 1998). However, for Ramphastidae, this information is very scarce (Feduccia, 1996; Sick, 1993). Three different approaches were available for the estimation of divergence times in our study: 1) the molecular estimate for the separation of Galloanserae from Neoaves 100 mya (Paton et al., 2002); 2) a mitochondrial DNA evolutionary rate of $2.0 \%$ per mya (Shields and Wilson, 1987; Kornegay et al., 1993; Klicka and Zink, 1997; Fleischer et al., 1998); and 3) the $0.5 \%$ rate for the
Table 3 - Branch length test under Tamura-Nei model of DNA substitution, assuming sequences to present rate heterogeneity of substitutions among sites $(\alpha=0.18)$.

\begin{tabular}{lcccc}
\hline First round & $\delta$ & s.e. & $\mathrm{Z}$ & $\mathrm{CP}(\%)$ \\
\hline Sphyrapicus varius & 0.057420 & 0.051990 & 1.104433 & 73 \\
Melanerpes carolinus & 0.022052 & 0.053797 & 0.409915 & 31 \\
Ramphastos toco & 0.041827 & 0.039701 & 1.053554 & 71 \\
Ramphastos tucanus & 0.110583 & 0.033448 & 3.306176 & $100^{*}$ \\
Capito dayi & 0.231403 & 0.086751 & 2.667438 & $99 *$ \\
Aulacorhynchus prasinus & 0.021010 & 0.041465 & 0.506683 & 38 \\
Selenidera maculirostris & 0.004389 & 0.039799 & 0.110276 & 9 \\
Andigena laminirostris & 0.031055 & 0.037044 & 0.838321 & 59 \\
Pteroglossus beauharnaesii & 0.022736 & 0.033860 & 0.671458 & 50 \\
Baillonius bailloni & 0.051756 & 0.042508 & 1.217565 & 77 \\
\hline Second round & $\delta$ & s.e. & $\mathrm{Z}$ & $\mathrm{CP}(\%)$ \\
\hline Sphyrapicus varius & 0.039310 & 0.050526 & 0.778013 & 56 \\
Melanerpes carolinus & 0.012249 & 0.052295 & 0.234230 & 18 \\
Ramphastos toco & 0.038504 & 0.043336 & 0.888497 & 62 \\
Aulacorhynchus prasinus & 0.037096 & 0.047058 & 0.788298 & 56 \\
Selenidera maculirostris & 0.007310 & 0.037159 & 0.196724 & 15 \\
Andigena laminirostris & 0.049645 & 0.038750 & 1.281157 & 80 \\
Pteroglossus beauharnaesii & 0.001073 & 0.039056 & 0.027479 & 2 \\
Baillonius bailloni & 0.069985 & 0.046223 & 1.514049 & 87 \\
\hline
\end{tabular}

Gallus gallus and Crax blumenbachii were used as outgroup. $\delta$ - expectation of no difference between branch lengths. s.e. - standard error. CP confidence probability. ${ }^{*}$ - significant at $5 \%$ level.

Note that $R$. tucanus adn $C$. dayi present significant rate variation in the first round of the test.

transversions occurring at third codon positions per mya (Irwin et al., 1991).

We decided for the first option for the following reasons: (1) the molecular estimate is supported by a body of evidence as shown, for instance, by the fossil record (e.g., Stidham, 1998) and also by mitochondrial and nuclear DNA sequences (e.g., van Tuinen and Hedges, 2001, 


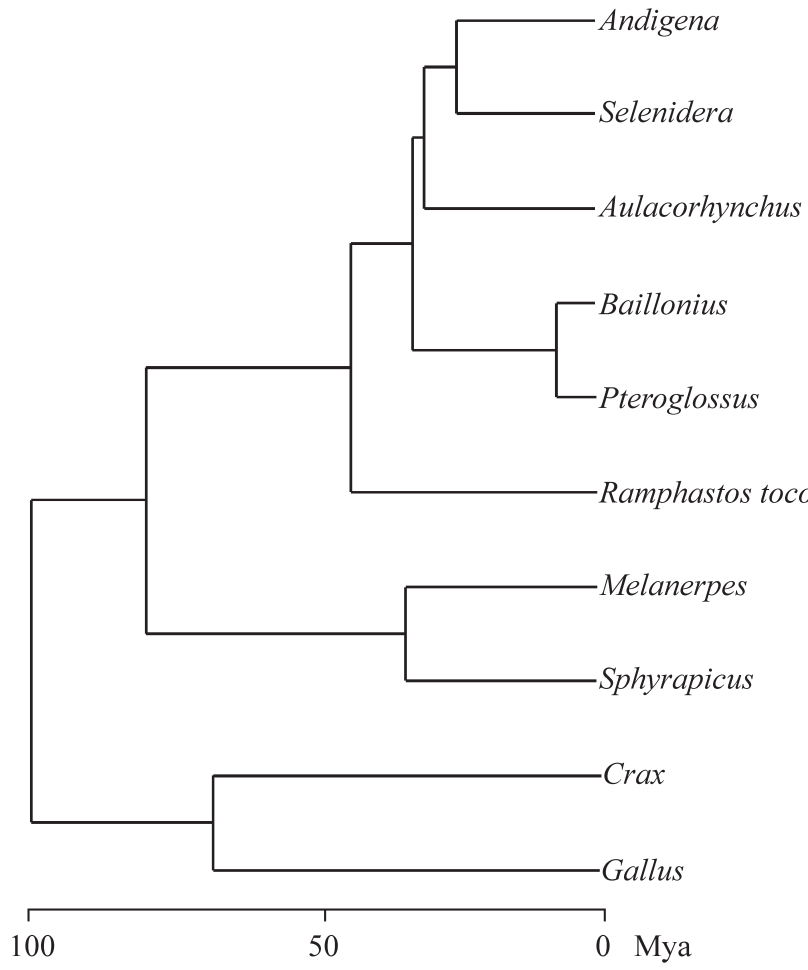

Figure 2 - Maximum likelihood clock tree under the transversional model with rate heterogeneity of DNA substitution among sites. Divergence times are indicated in a time scale below the phylogenetic hypothesis for those taxa evolving at a similar rate of DNA substitution. Gallus and Crax (Galliformes) were used as outgroup. Melanerpes and Sphyrapicus are members of Picidae, and the remaining taxa belong to Ramphastinae.

Table 4 - Divergence time estimates (in million years) for the Neotropical Ramphastinae and other Old World Piciformes, based on the divergence of Galliformes and other neognaths having occurred 100 million years ago (Paton et al., 2002).

\begin{tabular}{lcc}
\hline Taxon & $\begin{array}{c}\text { Divergence times } \\
( \pm \text { standard errors) }\end{array}$ & Geological time \\
\hline Baillonius x Pteroglossus & $9.5 \pm 1.5$ & Late Miocene \\
Andigena x Selenidera & $27.8 \pm 3.9$ & Late Oligocene \\
Aulacorhynchus & $34.4 \pm 3.7$ & Early Oligocene \\
Ramphastos & $46.8 \pm 5.4$ & Middle Eocene \\
Ramphastinae x other piciforms & $82.6 \pm 9.6$ & Late Cretaceous \\
Melanerpes x Sphyrapicus & $36.9 \pm 6.1$ & Eocene/Oligocene \\
\hline
\end{tabular}

Haddrath and Baker, 2001, Paton et al., 2002); (2) some groups seem to have evolved at rates other than the $2.0 \%$ sequence divergence per million years (Kessler and Avise, 1985); (3) using only transversions at the third codon positions would exclude $12 \mathrm{~S}$ rDNA sequences and reduce our data set to fewer base pairs, since not all third codon positions of the cyt $b$ sequences used here presented transversions, thus increasing the stochastic error in our estimates. Furthermore, the use of ancient calibration makes the estimation an interpolation rather than an extrapolation, which is inherently subject to greater errors.
The branch length tests indicated that the sequences of $R$. tucanus and C. dayi did not evolve at the same rate as the others. As pointed out by Barker and Lanyon (2000), there is non-stationarity in cyt $b$ third positions of Capito. Incidentally, this base composition effect explains the apparent rate increase in Capito reported here. By excluding $R$. tucanus and C. dayi from our data set, we were unable to reject a clock-like behavior for the remaining taxa.

Divergence times, as estimated here, indicate that the subfamily Ramphastinae, and probably the Capitoninae, diverged from other Piciformes in the Late Cretaceous, well before the Cretaceous/Tertiary $(\mathrm{K} / \mathrm{T})$ mass extinction events of 65 mya. Indeed, Cooper and Penny (1997) estimated, based on fossil calibrations, that at least 22 lineages of modern birds were diversified prior to the $\mathrm{K} / \mathrm{T}$ boundary. In their study, the authors did not include any member of Piciformes. Therefore, an important result of our study is the rise of the number of extant orders, which survived the $\mathrm{K} / \mathrm{T}$ mass extinction. Although suggesting a cause for the diversification of Ramphastidae is a difficult task, some events of Earth history may help fulfill the endeavor.

The separation of Ramphastidae from other Piciformes, as estimated here, also coincides with the separation of Africa from South America. These landmasses began to fragment around 120-130 mya due to sea-floor spreading and, by 90 mya, they were completely separated (Salgado-Labouriau, 1994). Some evidence exists that the terrestrial vertebrates could probably move through these landmasses until 80-70 mya (Sibley and Ahlquist, 1990, and references therein). The range of divergence times within the subfamily Ramphastinae estimated here includes the period from the Middle Eocene to the Late Miocene. Those epochs are known to have had intense geologic activities that drastically changed the Earth climate and geography (Briggs, 1987; Salgado-Labouriau, 1994). One of the major changes includes the rising of the Andes (Potts and Behrensmeyer, 1992; Marshall and Sempere, 1993) that modified the climate and the river basins throughout the South American continent. A large sea transgression covering extensive areas of central South America has also been reported for that time (Petri and Fulfaro, 1988). These events might have influenced dispersal and diversification of living organisms, by changing or generating new habitats and even new ecosystems. For instance, the divergence time estimated here between the mountain-toucans, Andigena, and their lowland sister-taxon, Selenidera, was around 27 mya. This time corresponds to a major period of Andean uplift (Potts and Behrensmeyer, 1992; Marshall and Sempere, 1993), and we could assume that Andigena became adapted to the greater altitudes provided by the newly formed Cordillera of the Andes.

Most members of the subfamily Ramphastinae live in forests, but several Pteroglossus species live in drier environments (Haffer, 1974). These environments are currently represented by the cerrado (Brazilian savanna) and caatinga 
(Brazilian semi-arid vegetation) biomes of Central and North-Eastern Brazil, respectively. We suggest that the drying out of central South America leading to the formation of the Brazilian savanna and the isolation of the Atlantic forest during the Miocene may have allowed the diversification of Pteroglossus from other toucans.

In conclusion, one of the significant results of our work was the inclusion of Ramphastidae among the lineages that survived the K/T extinction. Also, the uplift of the Andes during the Miocene and Eocene seems to have offered opportunities for the genera diversification of toucans, as well as of other Neotropical birds (Miyaki et al., 1998; Pereira et al., 2002) and of mammals (Cortés-Ortiz et al., 2003). These opportunities are related to geographic changes in South America, namely alterations in river basins, forest distribution, and formation of altitude and savanna-like habitats. A better understanding of how these processes influenced diversification within these groups should be provided by a more comprehensive study, increasing taxon sampling within Ramphastidae and other Neotropical groups (e.g. Cortés-Ortiz et al., 2003).

\section{Acknowledgments}

We thank Fundação Parque Zoológico de São Paulo, Maria de Lourdes Cavalheiro (Universidade Federal do Paraná), Maria Luiza Videira Marceliano (Museu Paraense Emílio Goeldi), Miguel Trefaut Urbano Rodrigues (Universidade de São Paulo), Parque Zoológico de Sorocaba, and Vitor Fasano and Carlos Keller (Criadouro Tropicus) who kindly provided tissue samples that are deposited at the Laboratório de Genética e Evolução Molecular de Aves do Depto de Biologia da Universidade de São Paulo, Brazil; Cristina Yumi Miyaki for invaluable suggestions and laboratory support; Mariana Cabral, Mari-Anne Van Sluys and Regina Yuri Hashimoto Miura for allowing the use of their automated DNA sequencer; Alexandre Magno Feitosa Sales, Elizabeth Höfling, Eugene Harris, Linda Amaral Zettler, Luís Fábio Silveira, Robert Blaquière, and two anonymous reviewers for helpful discussions and suggestions. Financial support was provided by $\mathrm{CNPq}$ (National Council for Scientific and Technological Development) and FAPESP (The State of São Paulo Research Foundation).

\section{References}

Alvarenga H (1993) Fossil Birds. In: Sick H (ed) Birds in Brazil. Princeton University Press, Princeton, pp 62-67.

Arnaiz-Villena A, Álvarez-Tejado M, Ruíz-del-Valle V, Garcíade-la-Torre C, Varela, P, Recio MJ, Ferre S and Martinez-Laso J (1999) Rapid radiation of canaries (genus Serinus). Mol Biol Evol 16:2-11.

Barker FK and Lanyon SM (2000) The impact of parsimony weighting schemes on inferred relationships among toucans and Neotropical barbets (Aves: Piciformes). Mol Phylogenet Evol 15:215-234.
Björklund M (1999) Are third positions really that bad? A test using vertebrate cytochrome $b$. Cladistics 15:191-197.

Briggs J (1987) Biogeography and plate tectonics. Developments in Paleontology and Stratigraphy, 10. Elsevier, Amsterdam, 204 pp.

Bruford MW, Hanotte O, Brookfield JFY and Burke T (1992) Single-locus and multilocus DNA fingerprinting. In: Hoezel AR (ed) Molecular Genetic Analysis of Populations - A practical approach. Oxford University Press, New York, pp 225-269.

Castro MS, Recco-Pimentel SM and Rocha GT (2002) Karyotypic characterization of Ramphastidae (Piciformes, Aves). Genet Mol Biol 25:147-150.

Cheng S, Fockler C, Barnes WM and Higuchi R (1994) Effective amplification of long targets from clones inserts and human genomic DNA. Proc Natl Acad Sci USA 91:5695-5699.

Cooper A and Penny D (1997) Mass survival of birds across the cretaceous tertiary boundary: molecular evidence. Science 275:1109-1113.

Cortés-Ortiz L, Bermingham E, Rico C, Rodríguez-Luna E, Sampaio I and Ruiz-García M (2003) Molecular systematics and biogeography of the Neotropical monkey genus, Alouatta. Mol Phylogenet Evol 26:64-81.

Desjardins P and Morais R (1990) Sequence and gene organization of the chicken mitochondrial genome - a novel gene order in higher vertebrates. J Mol Biol 212:599-634.

Edwards SV, Arctander P and Wilson AC (1991) Mitochondrial resolution of a deep branch in the genealogical tree for perching birds. Proc R Soc Lond B Biol Sci 243:99-107.

Espinosa de los Monteros A (2000) Higher-level phylogeny of trogoniformes. Mol Phylogenet Evol 14:20-34.

Feduccia A (1996) The origin and evolution of birds. Yale University Press. USA, $480 \mathrm{pp}$.

Felsenstein J (1981) Evolutionary trees from DNA sequences: a maximum likelihood approach. J Mol Evol 17:368-376.

Fleischer RC, McIntosh CE and Tarr CL (1998) Evolution on a volcanic conveyor belt: using phylogeographic reconstruction and K-Ar-based ages of the Hawaiian islands to estimate molecular evolutionary rates. Mol Ecol 7:533-545.

García-Moreno J and Mindell DP (2000) Rooting a phylogeny with homologous genes on opposite sex chromosomes (gametologs): A case study using avian CHD. Mol Biol Evol 17:1826-1832.

García-Moreno J and Silva JMC (1997) An interplay between forest and non-forest South American avifaunas suggested by a phylogeny of Lepidocolaptes woodcreepers (Dendrocolaptinae). Stud Neotrop Environ 32:164-173.

Haddrath O and Baker AJ (2001) Complete mitochondrial DNA genome sequences of extinct birds: ratite phylogenetics and the vicariance biogeography hypothesis. Proc R Soc Lond B Biol Sci 268:939-945.

Haffer J (1974) Avian Speciation in Tropical South America: With a Systematic Survey of the Toucans (Rampastidae) \& Jacamars (Galbulidae). Cambridge, Massachusetts, 390 pp.

Hästad O and Björklund M (1998) Nucleotide substitution models and estimation of phylogeny. Syst Zool 40:257-270.

Hedges SB, Parker PH, Sibley CG and Kumar S (1996) Continental breakup and the ordinal diversification of birds and mammals. Nature 381:226-229.

Höfling E (1998) Comparative cranial anatomy of Ramphastidae and Capitonidae. Ostrich 69:389-390. 
Huelsenbeck JP and Rannala B (1997) Phylogenetic methods come of age: testing hypothesis in an evolutionary context. Science 276:227-232.

Huelsenbeck JP, Larget B and Swofford D (2000) A compound Poisson process for relaxing the molecular clock. Genetics 154:1879-1892.

Irwin DM, Kocher TD and Wilson AC (1991) Evolution of the cytochrome $b$ gene of mammals. J Mol Evol 32:128-144.

Jeffreys AJ, Wilson V, Neumann RA and Keyne J (1988) Amplification of human minisatellites by the polymerase chain reaction: towards DNA fingerprinting of single cells. Nucleic Acids Res 16:10953-10971.

Källersjö M, Albert VA and Farris JS (1999) Homoplasy increases phylogenetic structure. Cladistics 15:91-93.

Kessler LG and Avise JC (1985) A comparative description of mitochondrial-DNA differentiation in selected avian and other vertebrate genera. Mol Biol Evol 2:109-125.

Klicka J and Zink RM (1997) The importance of recent ice ages in speciation: A failed paradigm. Science 277:1666-1669.

Kocher TD, Thomas WK, Meyer A, Edwards SV, Pääbo S, Villablanca FX and Wilson AC (1989) Dynamics of mitochondrial DNA evolution in animals: amplification and sequencing with conserved primers. Proc Natl Acad Sci USA 86:6196-6200.

Kornegay JR, Kocher TD, Williams LA and Wilson AC (1993) Pathways of lysozyme evolution inferred from the sequences of cytochrome $b$ in birds. J Mol Evol 37:367-379.

Kumar S, Tamura K, Jakobsen IB and Nei M (2001) MEGA2: Molecular Evolutionary Genetics Analysis software, Bioinformatics 17:1244-1245.

Lanyon SM and Hall JG (1994) Reexamination of barbet monophyly using mitochondrial-DNA sequence data. Auk 111:389-397.

Maddison WP and Maddison DR (1992) MacClade. Version 3.08. Sinauer, Sunderland, MA.

Marshall LG and Sempere T (1993) Evolution of the neotropical Cenozoid land mammal fauna in its geochronologic, stratigraphic, and tectonic context. In: Goldblatt P (ed) Biological relationships between Africa and South America. Yale University Press, New Haven, pp 329-392.

Miyaki CY, Matioli SR, Burke T and Wajntal A (1998) Parrot evolution and paleogeographical events: mitochondrial DNA evidence. Mol Biol Evol 15:544-551.

Parker SR (1997) Sequence Navigator. Multiple sequence alignment software. Methods Mol Biol 70:145-154.

Paton T, Haddrath O and Baker AJ (2002) Complete mitochondrial DNA genome sequences show that modern birds are not descended from transitional shorebirds. Proc R Soc Lond B Biol Sci 269:839-846.

Pereira SL, Baker AJ and Wajntal A (2002) Combining nuclear and mitochondrial DNA sequences resolve generic relationships within the Cracidae (Galliformes, Aves). Syst Biol 51:946-958.

Petri S and Fulfaro VJ (1988) Geologia do Brasil. Ed. Universidade de São Paulo, São Paulo, 631 pp.

Posada D and Crandall KA (1998) MODELTEST: testing the model of DNA substitution. Bioinformatics 14:817-818.
Potts R and Behrensmeyer AK (1992) Late Cenozoic terrestrial ecosystems. In: Bahrensmeyer AK, Damuth JD, DiMichele WA, Potts R, Sues HD and Wing SL (eds) Terrestrial ecosystems though time. University of Chicago Press, Chicago, pp 419-541.

Prum RO (1988) Phylogenetic interrelationships of the barbets (Aves: Capitonidae) and toucans (Aves: Ramphastidae) based on morphology with comparisons to DNA x DNA hybridization. Zool J Linn Soc 92:313-343.

Rambaut A and Bromham L (1998) Estimating divergence times from molecular sequences. Mol Biol Evol 15:442-448.

Russo CAM, Takezaki N and Nei M (1995) Molecular phylogeny and divergence times of Drosophilid species. Mol Biol Evol 12:391-404

Salgado-Labouriau ML (1994) História ecológica da Terra. Editora Edgard Blücher Ltda, São Paulo, 370 pp.

Sanderson MJ (1997) A nonparametric approach to estimating divergence times in the absence of rate constancy. Mol Biol Evol 14:1218-1231.

Shields GF and Wilson AC (1987) Calibration of mitochondrial DNA evolution in geese. J Mol Evol 24:212-217.

Sibley CG (1996) Birds of the world. Version 2.0, Thayer Birding Software.

Sibley CG and Ahlquist JE (1990) Phylogeny and classification of birds - a study in molecular evolution. Yale University Press, New Haven, 976 pp.

Sick H (1993) Birds in Brazil: A Natural History. Princeton University Press, Princeton, 932 pp.

Smith AB (1998) What does paleontology contribute to systematics in a molecular world? Mol Phylogenet Evol 9:437-447.

Stidham TA (1998) A lower jaw from a Cretaceous parrot. Nature 396:29-30.

Swofford DL (2002) PAUP*: Phylogenetic Analysis Using Parsimony (* and related methods). Version 4.0b8, Sinauer Associates, Massachusetts.

Takezaki N, Rzhetsky A and Nei M (1995) Phylogenetic test of the molecular clock and linearized trees. Mol Biol Evol 12:823-833.

Thompson JD, Higgins DG and Gibson TJ (1994) CLUSTALW: improving the sensitivity of progressive alignment through sequence weighting, position-specific gap penalties and weight matrix choice. Nucleic Acids Res 22:4673-4680.

Thorne JL, Kishino H and Painter IS (1998) Estimating the rate of evolution of the rate of molecular evolution. Mol Biol Evol 15:1647-1657.

van Tuinen M and Hedges SB (2001) Calibration of avian molecular clocks. Mol Biol Evol 18: 206-213

van Tuinen M, Sibley CG and Hedges SB (1998) Phylogeny and biogeography of ratite birds inferred from DNA sequences of the mitochondrial ribosomal genes. Mol Biol Evol 15:370-376.

Yoder AD and Yang Z (2000) Estimation of primate speciation dates using local molecular clocks. Mol Biol Evol 17:10811090.

Zhen L and Swank RT (1993) A simple and high yield method for recovering DNA from agarose gels. Biotechniques 14:894896.

Editor: Sérgio Furtado dos Reis 